\title{
Toward promoting effective strategic performance: the relevance of the alignment of performance measurement and competitive strategic choices
}

\section{Carlos F. Gomes*}

School of Economics,

University of Coimbra,

ISR-Institute of Systems and Robotics,

Av. Dias da Silva 165 - 3004-512 Coimbra, Portugal

Email: cfgomes@fe.uc.pt

*Corresponding author

\section{Mahmoud M. Yasin}

Department of Management and Marketing,

East Tennessee State University,

P.O. Box 70625 - Johnson City, TN 37614, USA

Email: mmyasin@ETSU.edu

\begin{abstract}
This research mainly examines the relationship among competitive methods, performance measures, and strategic orientations utilised by 68 Portuguese manufacturing organisations from different industries. The findings reveal that the surveyed organisations appear to be following a hybrid-mixed strategy. The group with the best results adopted the most balanced strategic approach, as it emphasised most of the different strategic dimensions. The examination of the strategic orientations, performance dimensions, and most utilised performance measures reveals inconsistencies among the surveyed organisations, which clearly indicates that the strategic choices and performance measures and measurements are misaligned. This study has direct practical implications to executives of manufacturing organisations, as they attempt to integrate their organisational systems in pursuit of effective strategic competitive performance. Based on the results of this study, a conceptual framework is proposed to facilitate the alignment among the competitive methods, performance measurement, and selected strategy.
\end{abstract}

Keywords: competitive methods; performance measurement; organisational strategy; effective strategic competitive performance.

Reference to this paper should be made as follows: Gomes, C.F. and Yasin, M.M. (2017) 'Toward promoting effective strategic performance: the relevance of the alignment of performance measurement and competitive strategic choices', Int. J. Business Excellence, Vol. 12, No. 3, pp.329-350.

Biographical notes: Carlos F. Gomes is an Associate Professor with Aggregation at the School of Economics at the University of Coimbra. He is a researcher at the Institute of Systems and Robotics in Coimbra, Portugal. He received his $\mathrm{PhD}$ and MS in Industrial Management, a post-graduate certificate of Advanced Studies in Industrial Quality and International Business, and a BS in Electrical Engineering, all from the University of Coimbra. His main research interests are performance management, operations strategy, and improvement of production systems. He has published in many refereed journals, and proceedings of professional meetings. 
Mahmoud M. Yasin holds a PhD in Industrial Management from Clemson University, a Professor of Management at East Tennessee State University. His research has appeared in such journals as the Journal of Operations Management, Omega, International Journal of Production and Operations Management, and Business Research. He has published more than 200 articles and papers. He currently serves on several editorial boards. He is the recipient of several teaching and research awards and recognitions.

This paper is a revised and expanded version of a paper entitled 'Promoting the consistency between business strategies followed by manufacturing organizations and their performance measurement approach: an empirical investigation' presented at the 51st MBAA International Conference, Chicago, USA, 25-27 March 2015.

\section{Introduction}

Due to the dynamic nature of emerging competitive forces and players, business organisations, internationally, are finding themselves in need of new strategic and performance management approaches. These business adjustments are necessary to capitalise on the demand in new markets, and in the process proactively address potential concerns (Melnyk et al., 2014). In recent years, strategic challenges faced by business organisations have intensified due to unmistakable trends toward emphasising a customer-orientation as well as an increasing utilisation of innovative operational technologies and practices (Cheng and Yam, 2006; Upadhaya et al., 2014). In this context, modern manufacturing integrated systems, information technologies, and electronic commerce/business are redefining operation and customer relations (Maguire et al., 2007). These new competitive and operational realities are leaving manufacturing organisations with no choice but to reengineer their strategic business models. In today's dynamic, globally competitive, technology-based, and customer-driven manufacturing environment, a static strategic orientation may not be sufficient. Thus, the need to implement competitive methods to create an innovative strategic orientation is more critical than ever before in order to secure strategic survival of manufacturing organisations.

In essence, today's organisations must move away from the static, closed system operational model to more of a dynamic, open system mode. In the process, these organisations must become more responsive to the demands of their stakeholders. This openness requires a blend of innovative and hybrid-mixed strategies, rather than a single pure generic strategy, which was the norm under the closed system orientation.

The classical model introduced by Porter's (1985) for generic business strategy has been widely researched and practiced. The premise of the classical Porter's generic strategy model was based on the choice of a single generic strategy, which either promoted efficiency (cost leadership) or differentiation. Under such model, mixed strategies were labelled as stuck-in-the-middle, and, furthermore, perceived as ineffective strategic choices. Many practitioners and academicians in various business settings have long considered this model as the cornerstone for organisational effective strategy (Campbell-Hunt, 2000). 
The Portuguese business environment was a case and point, where Porter's model was followed (Green et al., 1993; Marques et al., 2000; Jácome et al., 2002). Although this was the case, the dynamic nature of emerging competitive forces and increasing demands from sophisticated customers has forced many organisations to modify their strategic business approach. In this context, most organisations adopted a mixed strategy to cope with the new realities of the market place (Campbell-Hunt, 2000). In the process, there was a shift from the single, generic strategic model to hybrid-mixed dynamic approach to the strategic choice. This new strategic approach relies on combining different competitive methods, in order to shape a flexible organisational strategic orientation.

Recent changes in the competitive environment have posed new challenges and at the same time offered new opportunities to manufacturing organisations everywhere, However, this competitive environmental changes have force organisations re-evaluate their organisational performance, competitive methods and overall organisational strategic choices.

The competitive environment challenges stemming from changes related with economical, technological, costumer orientation, and strategic relations with suppliers, have exerted significant pressure on organisations in different business cultural settings to emphasise the different aspects of organisational performance (Tung et al., 2011; Veysel et al., 2012; De Leeuw et al., 2013).

In response to the demands placed upon today's organisations, the performance measurement and management field began to stress more the integration, the collaboration, and the strategic role of performance (Jakobsen et al., 2010; Srimai et al., 2011; Lima et al., 2011; Turhan and Vayvay, 2011; Bisbe and Malagueño, 2012; Sahu et al., 2014).

Motivated by the above, this research seeks to uncover the business orientation of Portuguese manufacturing firms, as they respond to the changing nature of the manufacturing global environment. Examining the current strategic approaches of Portuguese firms can lead to the identification of best strategic practices, which lend themselves to benchmarking implications. In this context, the strategic consistency among competitive methods utilised by the organisation, performance measures used, and the implied strategy is critical to the effectiveness of these organisations, helping them to improve their organisational alignment. The lack of this alignment, which can occur at many organisational levels, can result in misused resources and loss of competitiveness (McAdam et al., 2014). The lack of consistency between the performance measures used and the overall organisational strategy can produce devastating results over the long-term (Meybodi, 2015a).

The study at hand attempts to explore the presence of such strategic consistency among Portuguese organisations. For this purpose, data gathered from 68 Portuguese firms was evaluated using several statistical procedures including: factor, cluster, regression, and gap analysis in order to shed some light on the main research question of this study. The research question deals with determining the presence of or lack of strategic consistency among the studied organisations.

Such line of research has not been forthcoming despite its practical and theoretical significance. As organisations become more open system oriented in response to the changes and demands of their competitive environment, they will find it necessary to align their competitive methods with their performance measures practices in order to 
ensure a consistent strategic competitive posture in their pursuit of the competitive strategic advantage. In this context, the study attempts to integrate different bodies of knowledge in order to address this issue of strategic consistency.

Although the sample utilised consists of Portuguese organisations, the assessment of strategic consistency is relevant to organisations globally. Figure 1 conceptually shows the shift from the closed system mode of doing business to a more open one within the context of the desired strategic consistency. Figure 2 is offered based on the results of this study to today's organisations in order to promote strategic consistency. It emphasises the relationships between the organisation and its environment, as it offers a road map toward facilitating the achievement of the strategic consistency. Figure 2 is motivated by the lack of strategic consistency uncovered by the findings of this exploratory study. Although the field of strategy is vast and well researched, the research at hand mainly focuses on the issue of strategic consistency among competitive methods, performance measures, and the chosen strategy. This represents the contribution of this exploratory research. It has both theoretical and practical implications.

Theoretical insight gained with regard to the different relationships among performance measures, and the strategic choice resulting from the selected competitive methods should further our understanding of these theoretical constraints. In the process, this should facilitate formulating and refining theoretical frameworks which have relevance to both managers and scholars in this area. In this context, the main contribution of this study is to assess the presence, or lack of the needed strategic consistency among performance measures, competitive methods, and strategy in the emerging open system of today's organisation. This contribution has both theoretical and practical significance, as today's organisations move from the closed system mode of doing business to the open system mode in response to their customer oriented competitive environment.

Figure 1 A conceptual framework of manufacturing performance and strategic-orientation

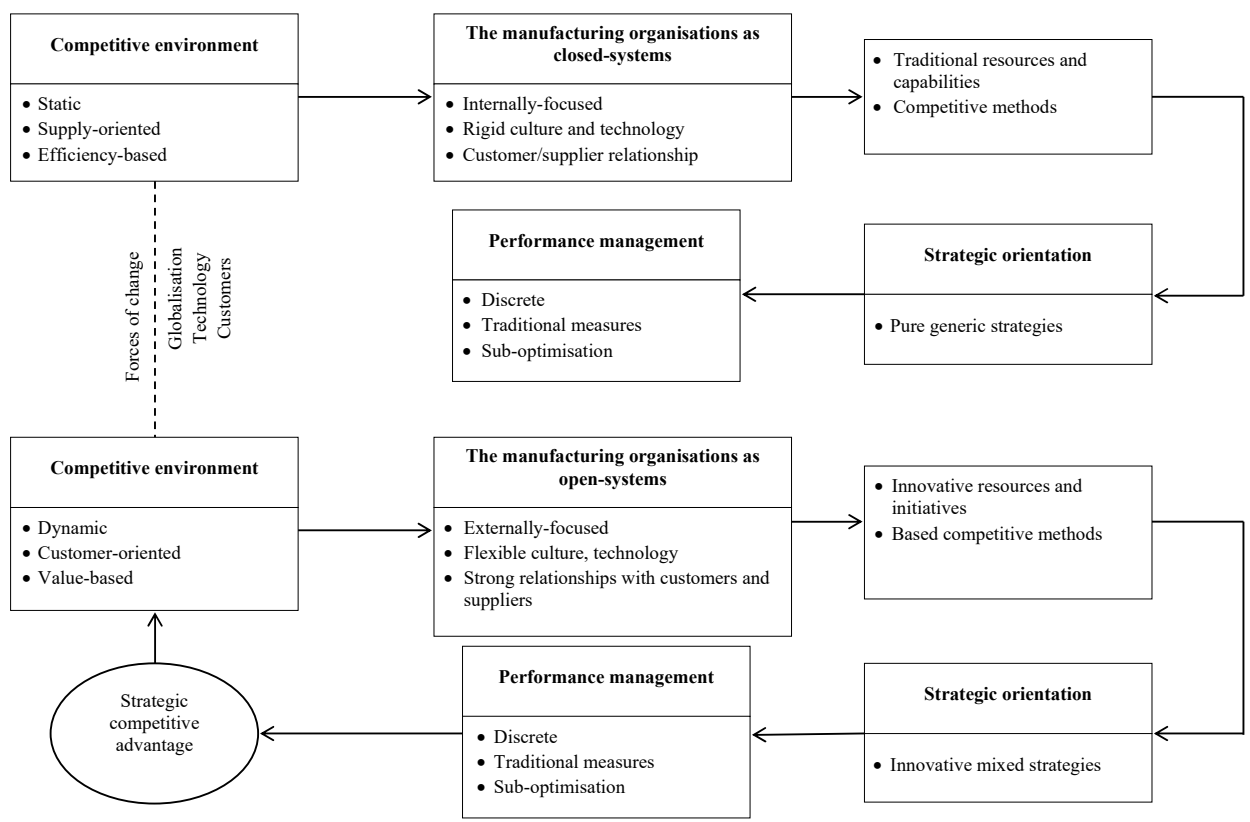


Figure 2 A strategic performance consistency-driven process (see online version for colours)

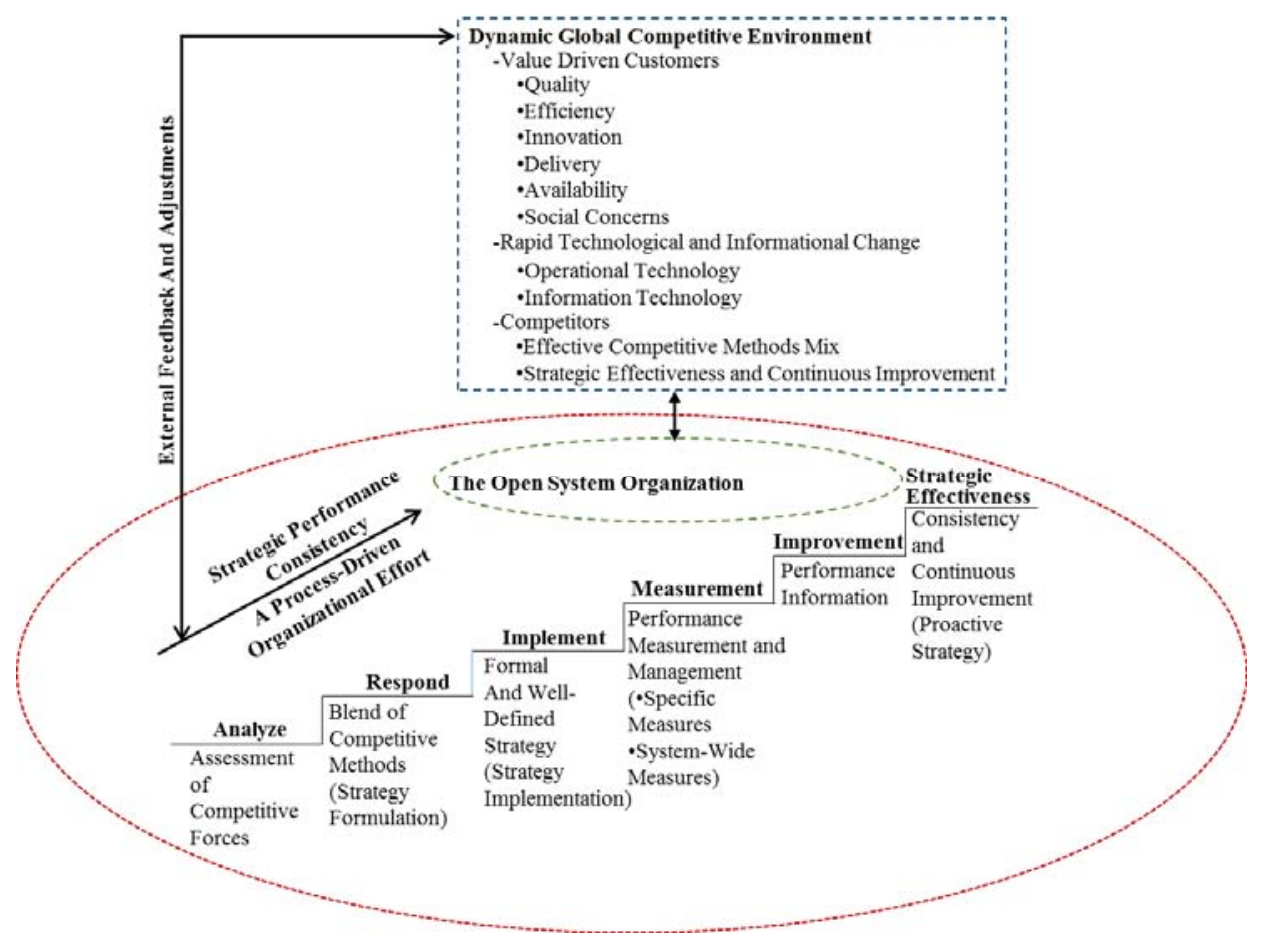

\section{Relevant literature}

Issues related to the consistency between strategy and performance measurement have been a subject of concern and debate for the last 30 years. Initially, some conceptual references were found regarding this important subject in the performance measurement literature. As such, it was believed that performance measurement systems (PMS) should be implemented as means of articulating strategy and monitoring business results (Grady, 1991). In this context, PMS should be aligned with business strategy (Powell, 1992; McNair and Mosconi, 1987; Drucker, 1990). Therefore, it was concluded that such systems must adapt accordingly with the evolving strategy (Bhimani, 1993).

More recently, the organisational role of PMS has taken on more significance. Therefore, the consistency between the PMS and strategy has been stressed (Meybodi, 2015b). In this context, the PMS is seen as an essential organisational system, which when aligned with the organisational strategy, is capable of promoting organisational responses to internal and external changes (Marchand and Raymond, 2008; Bisbe and Malagueño, 2012). Also, the PMS is instrumental to the development, implementation, and improvement of organisational strategy, as it fosters the alignment of key organisational capabilities and processes (Srimai et al., 2011; Taylor and Taylor, 2013; Oyewobi et al., 2015). The presence of a PMS tends to facilitate employees' awareness of the organisations strategic goals and objectives through the enhancement of the 
communication process (Tung et al., 2011; Belkasseh and Lemtaoui, 2015; Shahzileh and Aghajan, 2015).

The availability of a PMS system tends to assist organisations in managing their different activities in order to support their chosen strategies (Srimai et al., 2011; Olivella and Gregorio, 2015). A major benefit of having a PMS system is that it serves an important role in promoting organisational innovation (Aracioğlu et al., 2013). A significant part of the performance management system lies in its ability to host the relevant performance measures and in the process enhances the alignment of these measures with strategic objectives (Marinho and Cagnin, 2014).

While the body of knowledge dealing with strategy is rich and diverse, the relationships among the intended strategy, competitive methods utilised to achieve it, and performance measures used to gauge the different aspects of organisational performance are not as well established. Research dealing with the consistency among these three bodies of knowledge in practice, which includes internal strategy (pure generic or hybrid-mixed), competitive methods (traditional versus innovative), and performance measures (financial and operational versus organisational wide measures), is slow in forthcoming. Thus, the study at hand attempts to contribute toward that end.

Given the dynamic nature of strategic objectives dictated by today's changing competitive environment, the strategic alignment of performance measurement becomes the driver for organisational change. In the process, this tends to facilitate the strategic alignment needed to provide direction for the continuous improvement effort (Hudson Smith and Smith, 2007). Despite the high importance of this subject as revealed by the literature during the last 30 years, it seems that there is still very little empirical evidence with regard to the association between strategy and performance measurement (Hanson et al., 2011; Ho et al., 2013; Okongwu et al., 2015). Therefore, a clear consistency relationship is not easily assumed.

The literature points to the apparent difficulties associated with the implementation of this desired consistency relationship. Several references underline the difficulties of simultaneous changing strategic and operational objectives in order to promote consistency (Hanson et al., 2011). In this context, the literature also highlights the difficulties of maintaining this alignment between PMS and strategy, as it takes time to restate the strategic changes into reformulated measures and metrics. Furthermore, time is needed to effectively communicate and implement these changes throughout an entire organisation. Finally, in order to effectively implement such changes, the members of the organisation must accept the changes and adapt their conduct accordingly (Melnyk et al., 2014).

In general, the literature reviewed in relation to performance measurement, competitive methods, and the resulting strategic orientations clearly underscored the need for more research regarding the relationships among these important aspects of the manufacturing organisation. In this context, the match, or lack thereof, between the strategic orientation of a manufacturing organisation and the performance measurement approach utilised represents an area where more research is needed.

This is especially true in the case of today's organisations as they face a customer driven environment. As such, they must utilise mixed-hybrid strategies in order to satisfy the needs and wants of their value-seeking customers. Therefore, these organisations must align their competitive methods and performance measures with the new strategic approaches demanded by the customers. In this context, strategic consistency is needed in order to ensure a competitive strategic advantage in the dynamic marketplace. As 
organisations move more and more toward the open system mode of doing business, strategic consistency becomes more important as the relationships pertaining to competitive methods, performance measures, and strategic choices must be managed effectively. The closed system organisations of the near past only had to deal with a single generic strategy consistent with Porter's model.

Figure 1 conceptually depicts the shift of organisations from a single strategy closed system with selective competitive methods and performance measures to a more mixed-hybrid strategy open system with more competitive methods and performance measures to be coordinated and managed. In the process, Figure 1 incorporates the three elements interacting to promote strategic consistency. As such, Figure 1 is utilised to set the stage for the examination of strategic consistency, which is the objective of the current study. It is to be noted that the literature reviewed appears to agree on the importance of having strategic consistency. However, empirical research addressing the nature and the scope of the relationships, which are essential to ensure strategic consistency, is lacking. The current study attempts to fill this gap in the literature. Based on the results of this exploratory investigation, a road map practical approach is offered to the executives of the open system organisations as they attempt to achieve strategic consistency in a dynamic and customer driven environment. The proposed approach to ensure strategic consistency is conceptually depicted in the framework in Figure 2. In this context, both Figure 1 and Figure 2 are conceptual in nature and are not intended to establish causality. The causality issue is left for future research.

\section{Methods}

The current study is part of a research project focusing on organisational performance management. Specifically, it deals with performance measures, measurement, strategy implementation, and the impact on organisational competitiveness. For this purpose, a research questionnaire was designed based on previous works realised in Portugal by Jácome et al. (2002), and by Gomes et al. (2004).

In order to identify the executives' behaviour profile related to performance measurement, the questionnaire included 63 performance measures organised according to several dimensions, such as service quality and customer satisfaction, process efficiency, service and process innovation, competitive environment, quality/ independence of management, human resource management, and social responsibility. It is to be noted that executives are usually in charge of managing the strategic choice of their organisations. In the process, they deploy the appropriate competitive methods to achieve that choice and the performance measures needed to gauge them. Therefore, for each of these measures, Portuguese manufacturing executives were asked to indicate the predictive value, the information availability, and the extent of utilisation.

In order to identify the strategic practices, 33 competitive methods were also included in the questionnaire. Twenty of these competitive methods were derived from the work of Davis (1984). The strategic orientation of the Portuguese firms was contingent upon five dimensions (Jácome et al., 2002). In addition, seven new variables were introduced due to new competitive realities. These realities include the areas of: environmental health and safety in the work environment, information technology (IT), and electronic business related competitive methods. The extent of utilisation of these competitive methods was 
assessed using a Likert-type scale ranging from 1 (not utilised), to 5 (frequently utilised). The questionnaire was sent to a random sample of 500 organisations, with 50 employees or more, obtained from the database maintained by the governmental agency Portuguese National Institute of Statistics.

The data collection process ended with obtaining 68 completed responses. Forty research instruments were returned because the organisations either did not exist anymore, or were unwilling to participate in the study, this resulted to a response rate of approximately $15 \%$. The profile of the participant manufacturing organisations can be found in Table 1.

Table 1 Profile of participant manufacturing organisations

\begin{tabular}{|c|c|c|}
\hline Item & Frequency & Percentage \\
\hline \multicolumn{3}{|l|}{ Number of employers } \\
\hline From 50 to 99 & 14 & 20.6 \\
\hline From 100 to 199 & 23 & 33.8 \\
\hline From 200 to 499 & 19 & 28.0 \\
\hline From 500 to 999 & 3 & 4.4 \\
\hline 1,000 or more & 2 & 2.9 \\
\hline No response & 7 & 10.3 \\
\hline Total: & 68 & 100.0 \\
\hline \multicolumn{3}{|l|}{ Certification } \\
\hline Not implemented & 18 & 26.5 \\
\hline ISO 9000 & 31 & 45.6 \\
\hline ISO 14000 & 7 & 10.3 \\
\hline OHSAS 18000 & 4 & 5.9 \\
\hline Other standards & 6 & 8.8 \\
\hline No response & 10 & 14.7 \\
\hline \multicolumn{3}{|l|}{ Integrated PMS } \\
\hline Not implemented & 27 & 39.7 \\
\hline Production & 2 & 2.9 \\
\hline Production and one other department & 2 & 2.9 \\
\hline Production and two others departments & 2 & 2.9 \\
\hline Production and three others departments & 2 & 2.9 \\
\hline All departments & 13 & 19.1 \\
\hline Did not specified which departments & 2 & 2.9 \\
\hline No response & 18 & 26.5 \\
\hline Total: & 68 & 100.0 \\
\hline
\end{tabular}


The first phase of this research project was focused on investigating the existence of groups of organisations with similar strategic approaches. For this purpose, exploratory factor analysis was used to extract the dimensions representing the strategies followed by the organisations. Utilising the strategic dimensions obtained from the factor analysis procedure, a cluster analysis was used to group the organisations into strategic groups. Using Ward's method, the sample was reduced to 67 observations and the number of cluster was set on four.

The second phase of this research project was focused on obtaining the strategic group characterisation relating performance measuring practices, and their consistency with the strategies followed by the business organisations. For this purpose, multiple regression analysis was used to obtain the performance measurement profile of the executives, which belong to the organisations of each strategic group. In this context, the linear function to be estimated assumes that frequency of use (dependent variable) is a function of predicted value and ease of acquiring information for the performance measures as independent variables:

$$
\overline{F U_{i}}=\alpha_{0}+\alpha_{1} \overline{P V_{i}}+\alpha_{2} \overline{E A_{i}}+e_{i}
$$

$\overline{F U_{i}} \quad$ the mean frequency of use score on the $i^{\text {th }}$ measure

$\overline{P V_{i}} \quad$ the mean predictive value score on the $i^{\text {th }}$ measure

$\overline{E A_{i}} \quad$ the mean ease of acquisition score on the $i^{\text {th }}$ measure

$e_{i} \quad$ variable that represents the residual

$\alpha_{0}, \alpha_{1}, \alpha_{2}$ linear parameters.

The above function is designed to explain variation in the frequency of use of the performance measures. The observation unit was the average of the responses of all executives of each strategic group previously identified in the first phase of this research project.

A gap analysis was also used to help characterisation of the manufacturing organisations performance measurement practices. In this context, the equation below was used for each of the 63 performance measures.

$$
G A P_{i}=\left(P V_{i}-E A_{i}\right) P V_{i}
$$

It is to be noted that the gap equation above was derived from the literature (Foster and Gupta, 1994; Dempsey et al., 1997; Gomes et al., 2006). According to this equation, the larger GAP indicator is, the greater the disparity between the usefulness of the measure and its information availability. As such, the results of the gap equation have practical implications. They explain the predicted value of a measure (relevance) relative to the availability of information on that performance measure.

Finally, the relationship between profile of the executives in terms of the relative utilisation of financial and non-financial performance measures and their strategic orientations was analysed. 


\section{Results}

\subsection{Strategic approaches}

In the first phase of the data analysis, which was explained in the methodology section, the strategic approaches were identified. Using the principal component method with varimax rotation, five strategic dimensions with more than one variable were identified. The results of the Bartlett test, Kaiser-Myer-Olkin test, and sample overall adequacy $(0.70)$ indicates the appropriateness of the procedure used. This solution with five factors explains $51.07 \%$ of the total variance. The first factor highlights the importance that Portuguese manufacturing executives are giving to market leadership electing a set of competitive methods to achieve and to support that leadership. They are using e-commerce to help their leadership purpose. The second factor reveals the executives' concern to use specialised products and the process they use to achieve specific market targets. The third factor reveals the special attention that Portuguese manufacturing executives are devoting to continuous organisational innovation. Like in the first factor, manufacturing executives are using e-components to achieve their purpose. The fourth factor reveals the Portuguese executives' traditional concern for cost-leadership strategic approaches. However, they are using a hybrid-mixed approach, including a customer-service component.

Finally, the fifth factor of Portuguese manufacturing underscores a special concern with quality and reliability of organisational processes and practices, including variables such as quality management of products, processes and the organisation (ISO 9000 series), management of environmental systems (ISO 14000 series), and the management of the occupational health and safety system (OHSAS 18000 series).

This clearly indicates that Portuguese executives appear to have departed from the closed system single generic strategic orientation to more mixed hybrid strategies, which are more in tune with the demands of the open system dynamic organisation and its environment. Using the five strategic dimensions identified, a cluster analysis procedure was used. A four-cluster solution was obtained. Based on the cluster analysis results, the following strategic groups were identified:

- Strategic group A: This group includes 19 organisations (28.4\% of the sample).

- Strategic group B: This strategic group includes 25 organisations (37.3\% of the sample).

- Strategic group C: This strategic group includes eight organisations $(11.9 \%$ of the sample)

- Strategic group D: This group includes 15 firms (22.4\% of the sample).

\subsection{Strategic group characterisation}

The second phase of the research project, which was explained in the methodology section, begun by identifying the profile of the Portuguese manufacturing executives in relation to the utilisation of financial and non-financial performance measures. 
Based on the regression results (Table 2) a high percent of the total variability in the frequency of utilisation has been explained by the predictive value and ease of information acquisition. The estimated regression coefficients of all different profiles were found to be significant $(\alpha=0.01)$.

Table 2 Regression results relating profile of manufacturing executives of each strategic group

\begin{tabular}{lcccc}
\hline & Group A & Group B & Group C & Group D \\
\hline $\mathrm{R}^{2}$ & 0.845 & 0.923 & 0.813 & 0.885 \\
\hline \multicolumn{5}{c}{ Unstandardised coefficients } \\
\hline (Constant) & -0.693 & -0.749 & -0.531 & -0.574 \\
Predictive value & 0.643 & 0.754 & 0.650 & 0.820 \\
Ease [of] acquiring information & 0.493 & 0.427 & 0.403 & 0.283 \\
\hline
\end{tabular}

Notes: Dependent variable: frequency of utilisation.

All the coefficients are significant $(\alpha=0.01)$.

One may speculate that organisations of each strategic group, due to different strategic orientations, may tend to emphasise certain performance aspects in comparison to their counterparts. Due to the potential link between strategy orientation and performance measurement practices, this issue was explored using the model below:

$$
\overline{F U_{i}}=\alpha_{0}+\alpha_{1} \overline{P V_{i}}+\alpha_{2} \overline{E A_{i}}+\alpha_{3} S G_{i}+e_{i}
$$

In the above model, frequency of use (dependent variable) is assumed to be a function of the predicted value of a given performance measure, the ease of acquiring information on that measure, as well as the strategic group where the organisation falls as dependent variables. Therefore, $S G_{i}$ is a binary variable. This variable assumes the value of 1 , if an executive represents a manufacturing organisation belonging to a specific strategic group, and the value of 0 , if an executive represents a manufacturing organisation belonging to another specific strategic group.

Based on the results of all paired models, the coefficient of the variable SG only was found statistically significant $(\alpha=0.05$ ) for the pairs $\mathrm{AB}, \mathrm{BC}$ and $\mathrm{BD}$. Therefore, it is concluded that significant differences exist between the executives of strategic group $\mathrm{B}$ and the executives of all the other three strategic groups with respect to the profile of utilisation of the measures studied.

\subsubsection{Group A}

According to the results, manufacturing organisations included in strategic group A are following a hybrid-mixed strategic approach equally emphasising all dimensions except for quality and reliability (Table 3). According to Porter's model, this strategic behaviour is considered as stuck-in the middle. The firms in this group appear to neglect the importance of certification and the reliability of raw materials. 
Table 3 Strategic profile of group A

\begin{tabular}{|c|c|c|c|c|}
\hline Strategic orientations & Relevance & Performance dimensions & $F U$ & $G A P$ \\
\hline Efficiency and service & $4.596(2)$ & Financial & 3.84 & -0.04 \\
\hline Production and products & $3.874(2)$ & Process efficiency & 3.49 & -0.07 \\
\hline Market leadership & $3.843(1)$ & Human resource management & 3.25 & 0.70 \\
\hline Organisational innovation & $3.816(2)$ & $\begin{array}{l}\text { Product quality and customer } \\
\text { satisfaction }\end{array}$ & 3.23 & 0.60 \\
\hline \multirow[t]{4}{*}{ Quality and reliability } & $2.648(4)$ & Competitive environment & 3.15 & 0.95 \\
\hline & & $\begin{array}{l}\text { Quality/independence of } \\
\text { management }\end{array}$ & 2.96 & 0.93 \\
\hline & & Social responsibility & 2.91 & 0.68 \\
\hline & & Product and process innovation & 2.64 & 0.31 \\
\hline $\begin{array}{l}\text { Most relevant competitive } \\
\text { methods }\end{array}$ & & $\begin{array}{l}\text { Most used performance } \\
\text { measures }\end{array}$ & $F U$ & $G A P$ \\
\hline Customer service & 4.79 & Sales & 4.63 & 0.57 \\
\hline Operating efficiency & 4.74 & Earnings per share & 4.26 & -1.71 \\
\hline Meeting delivery dates & 4.58 & Safety record & 4.12 & -1.99 \\
\hline Product quality control & 4.53 & EBIT\&EI $\div$ Sales & 4.05 & 0.85 \\
\hline Brand identification & 4.42 & $\begin{array}{l}\text { Percent of products rejected by } \\
\text { the quality control }\end{array}$ & 4.05 & 0.04 \\
\hline New product development & 4.32 & Accounts receivable $\div$ Sales & 4.00 & -0.90 \\
\hline Experienced/trained personnel & 4.26 & Product cycle time & 3.94 & -0.50 \\
\hline $\begin{array}{l}\text { Product and service quality } \\
\text { improvement }\end{array}$ & 4.26 & $\begin{array}{l}\text { Actual production } \div \text { Planned } \\
\text { production }\end{array}$ & 3.94 & -0.68 \\
\hline \multicolumn{2}{|l|}{ Industries. and firm dimension } & $\begin{array}{l}\text { Most important performance } \\
\text { measures }\end{array}$ & $V P$ & $G A P$ \\
\hline \multicolumn{2}{|l|}{ Textile mill products } & Sales & 4.75 & 0.57 \\
\hline \multicolumn{2}{|c|}{$\begin{array}{l}\text { Paper and paper products. and publishing } \\
\text { industries }\end{array}$} & Employee training & 4.40 & 2.02 \\
\hline \multicolumn{2}{|l|}{ Chemicals and allied products } & $\begin{array}{l}\text { Experience/reputation of } \\
\text { management }\end{array}$ & 4.27 & 3.54 \\
\hline \multicolumn{2}{|c|}{ Rubber and miscellaneous plastics products } & EBIT\&EI $\div$ Sales & 4.25 & 0.85 \\
\hline \multicolumn{2}{|c|}{ Other non-metallic mineral products } & Product diversification & 4.25 & 1.53 \\
\hline \multicolumn{2}{|c|}{$\begin{array}{l}\text { Primary metals industries. and metal } \\
\text { products }\end{array}$} & Cash flow & 4.19 & 1.26 \\
\hline \multicolumn{2}{|c|}{ Miscellaneous machinery and equipment } & Continuity of management & 4.07 & 1.55 \\
\hline \multicolumn{2}{|c|}{ Transport equipment } & Employee involvement & 4.07 & 2.44 \\
\hline \multicolumn{5}{|c|}{ Miscellaneous manufacturing industries } \\
\hline \multicolumn{2}{|c|}{$\begin{array}{l}\text { Firm's dimension (average no. workers): } \\
177 \text { (3) }\end{array}$} & & & \\
\hline
\end{tabular}

Notes: - Numbers in parentheses are ranks of scores of strategic dimensions in descending order along the groups.

- Strategic orientations are sorted according to their relevance within each strategic group.

- Performance dimensions are sorted according to their utilisation within each strategic group. 
Their performance measuring profile is showing a low utilisation of important performance dimensions, such as the product and process innovation, the social responsibility, and the quality of management. This profile also shows a clear misalignment of competitive methods and performance measurement approach. The model representing their performance profile (Table 2) shows that the performance measures utilisation is more sensitive to the predictive value, than to the information availability. However, surveyed organisations appear unwilling to pay for the information needed to promote the utilisation of measures that could improve their strategic competitiveness. Although assuming customer service and meeting delivering dates as the most relevant competitive methods, they concentrate their efforts on measuring process efficiency and financial performance.

\subsubsection{Group B}

Manufacturing organisations of group B seem to adopt a somewhat balanced approach to their strategic orientation to deal with the new business realities. These firms only appear to relatively undermine one strategic dimension, which is market leadership (Table 4).

Table 4 Strategic profile of group B

\begin{tabular}{|c|c|c|c|c|}
\hline Strategic orientations & Relevance & Performance dimensions & $F U$ & $G A P$ \\
\hline Efficiency and service & $4.667(1)$ & Financial & 4.09 & -1.20 \\
\hline Quality and reliability & $4.393(1)$ & $\begin{array}{l}\text { Product quality and } \\
\text { customer satisfaction }\end{array}$ & 3.89 & 0.19 \\
\hline Production and products & $4.276(1)$ & $\begin{array}{l}\text { Human resource } \\
\text { management }\end{array}$ & 3.86 & -0.19 \\
\hline Organisational innovation & $4.203(1)$ & Process efficiency & 3.83 & -0.19 \\
\hline \multirow[t]{4}{*}{ Market leadership } & $3.533(2)$ & $\begin{array}{l}\text { Product and process } \\
\text { innovation }\end{array}$ & 3.62 & -0.78 \\
\hline & & Competitive environment & 3.41 & 0.64 \\
\hline & & Social responsibility & 3.37 & 0.43 \\
\hline & & $\begin{array}{l}\text { Quality/independence of } \\
\text { management }\end{array}$ & 3.33 & -0.66 \\
\hline Most relevant competitive methods & & $\begin{array}{l}\text { Most used performance } \\
\text { measures }\end{array}$ & $F U$ & $G A P$ \\
\hline Customer service & 4.80 & Sales & 4.88 & -0.57 \\
\hline Product quality control & 4.80 & $\begin{array}{l}\text { Percent of products rejected } \\
\text { by the quality control }\end{array}$ & 4.63 & -0.41 \\
\hline Meeting delivery dates & 4.80 & Cash flow & 4.56 & -1.20 \\
\hline New product development & 4.78 & EBIT\&EI $\div$ Sales & 4.52 & -0.18 \\
\hline Operating efficiency & 4.76 & Safety record & 4.46 & -0.56 \\
\hline Product and service quality improvement & 4.64 & Absentee rates & 4.36 & -0.51 \\
\hline Procurement of raw materials & 4.56 & Employee training & 4.32 & 0.17 \\
\hline $\begin{array}{l}\text { Continuous improvement of production } \\
\text { process }\end{array}$ & 4.56 & Equity $\div$ Total assets & 4.29 & -1.45 \\
\hline
\end{tabular}

Notes: - Numbers in parentheses are ranks of scores of strategic dimensions in descending order along the groups.

- Strategic orientations are sorted according to their relevance within each strategic group.

- Performance dimensions are sorted according to their utilisation within each strategic group. 
Table 4 Strategic profile of group B (continued)

\begin{tabular}{|c|c|c|c|}
\hline Industries and firm dimension & $\begin{array}{l}\text { Most important performance } \\
\text { measures }\end{array}$ & $V P$ & $G A P$ \\
\hline Food. [,] beverages and tobacco products & Sales & 4.76 & -0.57 \\
\hline Textile mill products & $\begin{array}{l}\text { Percent of products rejected by } \\
\text { the quality control }\end{array}$ & 4.54 & -0.41 \\
\hline Wood and cork products & EBIT\&EI $\div$ Sales & 4.48 & -0.18 \\
\hline Chemicals and allied products & Employee training & 4.36 & 0.17 \\
\hline Rubber and miscellaneous plastics products & Safety record & 4.33 & -0.56 \\
\hline Other non-metallic mineral products & Percent of missed delay dates & 4.33 & 0.52 \\
\hline Primary metals industries. and metal products & Cash flow & 4.28 & -1.20 \\
\hline Miscellaneous machinery and equipment & Absentee rates & 4.24 & -0.51 \\
\hline \multicolumn{4}{|l|}{ Electrical equipment } \\
\hline \multicolumn{4}{|l|}{ Transport equipment } \\
\hline \multicolumn{4}{|l|}{ Miscellaneous manufacturing industries } \\
\hline $\begin{array}{l}\text { Firm's dimension (average no. workers): } \\
230 \text { (2) }\end{array}$ & & & \\
\hline
\end{tabular}

Notes: - Numbers in parentheses are ranks of scores of strategic dimensions in descending order along the groups.

- Strategic orientations are sorted according to their relevance within each strategic group.

- Performance dimensions are sorted according to their utilisation within each strategic group.

According to the regression results, the performance measuring profile of organisations included in the strategic group B is significantly different (0.01) from organisations included in all the other strategic groups. Their performance measuring profile is showing a low utilisation of important performance dimensions, such as the competitive environment, the social responsibility, and the quality of management. However, this level of utilisation is above the average found in other strategic groups.

As in the case of the organisations of the strategic group A, the model related to their performance profile (Table 2) shows that the performance measures utilisation is more sensible to the predictive value than to the information availability. However, in this case it seems to be sufficient to promote the utilisation of some measures that could improve their strategic competitiveness. The results also show that executives of these organisations are in the right approach to the alignment between the strategic orientations and the performance measurement process. They are using the measures that are found to be most predictive. They also invested to have the information related to these measures available to be used. Some gaps were found, namely the information related to delay dates. 


\subsubsection{Group $C$}

Group C consists of firms that undermine four of the five strategic dimensions (Table 5).

Table 5 Strategic profile of group C

\begin{tabular}{|c|c|c|c|c|}
\hline Strategic orientations & Relevance & Performance dimensions & $F U$ & GAP \\
\hline Efficiency and service & $4.165(4)$ & Financial & 3.71 & -2.87 \\
\hline Quality and reliability & $3.250(3)$ & Human resource management & 2.89 & -0.40 \\
\hline Production and products & $2.550(4)$ & $\begin{array}{l}\text { Product quality and customer } \\
\text { satisfaction }\end{array}$ & 2.64 & -0.90 \\
\hline Organisational innovation & $2.344(4)$ & Process efficiency & 2.54 & -1.20 \\
\hline \multirow[t]{4}{*}{ Market leadership } & $1.916(4)$ & $\begin{array}{l}\text { Quality/independence of } \\
\text { management }\end{array}$ & 2.20 & -0.98 \\
\hline & & Social responsibility & 2.08 & -0.20 \\
\hline & & Competitive environment & 2.02 & -0.19 \\
\hline & & $\begin{array}{l}\text { Product and process } \\
\text { innovation }\end{array}$ & 1.26 & 1.10 \\
\hline $\begin{array}{l}\text { Most relevant competitive } \\
\text { methods }\end{array}$ & & $\begin{array}{l}\text { Most used performance } \\
\text { measures }\end{array}$ & $F U$ & GAP \\
\hline Competitive pricing & 4.50 & Sales & 4.86 & -1.90 \\
\hline Meeting delivery dates & 4.50 & Earnings per share & 4.71 & -4.39 \\
\hline Product quality control & 4.38 & Cash flow & 4.43 & -2.20 \\
\hline Operating efficiency & 4.25 & EBIT\&EI $\div$ Sales & 4.29 & 0.62 \\
\hline Customer service & 4.13 & Operating costs per employee & 4.29 & -3.29 \\
\hline Experienced/trained personnel & 4.13 & Sales per employee & 4.29 & -3.87 \\
\hline Procurement of raw materials & 3.88 & Safety record & 4.29 & -2.57 \\
\hline Reputation within industry & 3.88 & Equity $\div$ Total assets & 4.14 & -3.88 \\
\hline $\begin{array}{l}\text { Industries and firm } \\
\text { dimension }\end{array}$ & & $\begin{array}{l}\text { Most important performance } \\
\text { measures }\end{array}$ & $V P$ & GAP \\
\hline Food. [,] beverages and tobacco & lucts & Sales & 4.43 & -1.90 \\
\hline Textile mill products & & EBIT\&EI $\div$ Sales & 4.43 & 0.62 \\
\hline $\begin{array}{l}\text { Paper and paper products. [,] an } \\
\text { industries }\end{array}$ & plishing & Cash flow & 3.86 & -2.20 \\
\hline \multirow{4}{*}{\multicolumn{2}{|c|}{ Transport equipment }} & Employee training & 3.86 & 1.12 \\
\hline & & $\begin{array}{l}\text { Actual production } \div \text { Planned } \\
\text { production }\end{array}$ & 3.71 & 0.52 \\
\hline & & Capacity utilisation & 3.71 & 1.04 \\
\hline & & Safety record & 3.57 & -2.57 \\
\hline \multicolumn{2}{|c|}{$\begin{array}{l}\text { Firm's dimension (average no. workers): } \\
158 \text { (4) }\end{array}$} & Customer surveys & 3.57 & 1.54 \\
\hline
\end{tabular}

Notes: - Numbers in parentheses are ranks of scores of strategic dimensions in descending order along the groups.

- Strategic orientations are sorted according to their relevance within each strategic group.

- Performance dimensions are sorted according to their utilisation within each strategic group. 
"Market Leadership and Organizational Innovation" was the least emphasised strategic dimension. The organisations in this group appear to be at a strategic loss, especially with regards to innovation. Needless to say, these organisations are overlooking the significance of the customer-orientation in their strategic choices.

Their performance measuring profile is showing a low utilisation of important performance dimensions, such as the product and process innovation, the social responsibility, and the competitive environment. The model representing their performance profile (Table 2) shows that the performance measures utilisation is more sensible to the predictive value than to the information availability. However, the most used performance measures are the ones with the most information availability. On the other hand, executives of these organisations are not willing to pay for the information related to performance measures that they associated with higher predictive values, such as employee, and customer related measures.

The results also show that executives of these organisations are attempting to align the strategic orientations with the performance measurement process. However, it appears that they are approaching this alignment with a closed mindset, as they are still operating under the closed system orientation. The open-system orientation of today's organisations dictates a consistent strategic alignment between strategic choices and performance, while promoting the interaction between the organisation and its customers, suppliers, and its environment.

\subsubsection{Group D}

Group D consists of firms that are adopting a hybrid-mixed strategy. This can be seen as all of the strategic dimensions are in mid-level range with respect to other groups (Table 6). Firms in this group assigned the lowest value to the strategic dimension of market leadership.

Table 6 Strategic profile of group D

\begin{tabular}{lclcc}
\hline Strategic orientations & Relevance & Performance dimensions & FU & GAP \\
\hline Efficiency and service & $4.312(3)$ & $\begin{array}{l}\text { Product quality and customer } \\
\text { satisfaction }\end{array}$ & $3.69-0.59$ \\
Quality and reliability & $4.090(2)$ & Financial & $3.55-1.92$ \\
Production and products & $3.800(3)$ & Human resource management & $3.31-0.50$ \\
Organisational innovation & $3.583(3)$ & Process efficiency & $3.08-0.17$ \\
Market leadership & $2.367(3)$ & Social responsibility & 2.87 & 0.34 \\
& & Quality/independence of & $2.57-0.82$ \\
& & management & Competitive environment \\
& & Product and process innovation & 2.52 & 0.61 \\
& & & -1.03 \\
\hline
\end{tabular}

Notes: - Numbers in parentheses are ranks of scores of strategic dimensions in descending order along the groups.

- Strategic orientations are sorted according to their relevance within each strategic group.

- Performance dimensions are sorted according to their utilisation within each strategic group. 
Table 6 Strategic profile of group D (continued)

\begin{tabular}{|c|c|c|c|c|}
\hline \multicolumn{2}{|l|}{$\begin{array}{l}\text { Most relevant competitive } \\
\text { methods }\end{array}$} & \multirow{2}{*}{$\begin{array}{l}\text { Most used performance } \\
\text { measures } \\
\text { Sales }\end{array}$} & \multirow{2}{*}{$\begin{array}{l}F U \\
4.87\end{array}$} & \multirow{2}{*}{$\begin{array}{r}G A P \\
-1.79\end{array}$} \\
\hline Meeting delivery dates & 4.73 & & & \\
\hline Customer service & 4.47 & Sales $\div$ Total assets & 4.43 & -3.07 \\
\hline Operating efficiency & 4.4 & Equity $\div$ Total assets & 4.40 & -2.05 \\
\hline Product quality control & 4.33 & Warranty claims & 4.29 & -0.90 \\
\hline Procurement of raw materials & 4.33 & Return on equity & 4.27 & -2.20 \\
\hline Low production costs & 4.33 & Safety record & 4.27 & -1.55 \\
\hline $\begin{array}{l}\text { Product and service quality } \\
\text { improvement }\end{array}$ & 4.33 & Cash flow & 4.20 & -1.28 \\
\hline $\begin{array}{l}\text { Continuous improvement of } \\
\text { production process }\end{array}$ & 4.33 & Return on assets & 4.13 & -2.66 \\
\hline \multicolumn{2}{|l|}{$\begin{array}{l}\text { Industries. and firm } \\
\text { dimension }\end{array}$} & $\begin{array}{l}\text { Most important performance } \\
\text { measures }\end{array}$ & $V P$ & $G A P$ \\
\hline \multicolumn{2}{|c|}{ Food. [,] beverages and tobacco products } & Sales & 4.47 & -1.79 \\
\hline \multicolumn{2}{|l|}{ Textile mill products } & Percent of missed delay dates & 4.14 & 0.29 \\
\hline \multicolumn{2}{|c|}{ Rubber and miscellaneous plastics products } & Warranty claims & 4.07 & -0.90 \\
\hline \multicolumn{2}{|c|}{ Primary metals industries. and metal products } & $\begin{array}{l}\text { Percent of sales from } \\
\text { proprietary products }\end{array}$ & 4.00 & 3.00 \\
\hline \multicolumn{2}{|c|}{ Miscellaneous machinery and equipment } & Quality of accounting policies & 3.93 & 0.94 \\
\hline \multicolumn{2}{|l|}{ Electrical equipment } & Customer surveys & 3.93 & 0.24 \\
\hline \multicolumn{2}{|l|}{ Transport equipment } & Customer complaints & 3.93 & -0.28 \\
\hline \multicolumn{2}{|c|}{ Miscellaneous manufacturing industries } & Order to delivery time & 3.92 & 1.18 \\
\hline \multicolumn{5}{|c|}{$\begin{array}{l}\text { Firm's dimension (average no. workers): } \\
328 \text { (1) }\end{array}$} \\
\hline \multicolumn{5}{|c|}{$\begin{array}{l}\text { Notes: - Numbers in parentheses are ranks of scores of strategic dimensions in } \\
\text { descending order along the groups. } \\
\text { - Strategic orientations are sorted according to their relevance within each } \\
\text { strategic group. } \\
\text { - Performance dimensions are sorted according to their utilisation within each } \\
\text { strategic group. }\end{array}$} \\
\hline
\end{tabular}

Their performance measuring profile is showing a low utilisation of important performance dimensions, such as the process innovation, the competitive environment, and the quality of management. The model representing their performance profile (Table 2) shows that the performance measures utilisation is much more sensible to the predictive value than to the information availability. However, the most used performance measures are the ones with the most information availability.

It is interesting to note an alignment between the measures they assigned highest predictive value and the competitive methods they used to implement their intended strategy. It seems that they know exactly what to use to measure performance, but similar to Group $\mathrm{C}$, they are not willing to pay the cost required to obtain the needed information. However, upon the examination of the frequency with which these measures are being used, they are found among the top utilised measures. 
Overall, given the cluster analysis results, it is clear that the surveyed organisations are following a hybrid-mixed strategy. Group B appears to utilise the most balanced strategic approach, as it emphasises most of the different strategic dimension. Therefore, although there is no strategic group, which can truly serve as a benchmark for organisations in all other groups, organisations in group B are the closest to fulfilling that role. This is due to the higher than average relevance that Group B assigned each of the five strategic dimensions. The examination of the strategic dimensions, performance dimensions, most utilised measures, and most relevant measures, reveals some inconsistencies, which clearly indicate that the strategic choices and performance measures and measurements are misaligned. This is true for some strategic groups more so than others. In this context, the strategic consistency among performance measurements used, competitive methods utilised, and the resulting strategic orientations derived from them appears to be the exception rather than the norm.

Therefore, based on the results of this study, it appears that managers of today's organisations are broadening their perspective regarding both performance measures utilities as well as the competitive methods deployed with some exceptions. In this context, managers of today's organisations appear to be moving toward the open system organisational model of doing business. However, and perhaps more important, the results reveal that the consistency among performance measures, competitive methods, and the selective strategy is lacking. As such, more applied research pertaining to the strategic consistency is needed.

\section{Conclusions and implications}

The central research question examined in this exploratory research dealt with the presence of strategic consistency among open system organisations. In order to address this question, 33 competitive methods, 63 performance measures derived from the literature and the resulting strategic choices were examined.

Utilising a sample of 68 Portuguese manufacturing organisations, factor analysis and cluster analysis procedures were used to assess the relationships between the different facets of strategic competitive methods and performance measurement. Based on the results of this study and the reviewed literature, the following conclusions and implications are presented.

First, while some organisations are still operating under the closed-system orientation in terms of competitive methods, strategic choices, and performance measurement, the majority of the studied organisations appear to be moving towards the open-system business model. Such business model emphasises the openness to the competitive environment and therefore it dictates the consistent and systematic utilisation of competitive methods, strategic choices, and performance measurement in order to meet the changing demands of the dynamic marketplace.

Second, while the studied organisations are showing more willingness to utilise effective, mixed strategies through combining innovative competitive methods, some organisations are still adhering to the rigid strategic choices of the generic strategic model. While generic strategies which emphasised one aspect of organisational performance were suitable under the static competitive environment of the past, they will not be capable of responding to the increasing customer oriented dynamic competitive 
marketplace of the present. Such dynamic competitive environment requires a multifaceted organisational strategy, which ensures the customer-orientation.

Third, most organisations studied appear to be using performance measures consistently based on the relevance of the measure and its availability of information. In this context, the extent of use of these measures is explained by their predictive value and their information availability. However, the utilisation of some key measures related to customer, environment, and social responsibility signifies an inconsistent behaviour. This may be attributed to the lack of information on these measures, or underestimating their relevance. Investments in IT should provide the needed information. On the other hand, educating managers on the strategic potential of these measures should alleviate the problem of lack of utilisation.

Finally, the strategic consistency among competitive methods, performance measures, and strategic choices appears to be lacking. Most organisations studied still appear to view strategic competitive methods and strategy independent of performance measurement and management. This lack of consistency appears to be leading to a strategic-performance confusion. This conclusion has broader organisational implications. This is especially true in today's competitive marketplace.

\subsection{Implications and recommendations}

As these organisations attempt to be more customer-oriented, they must ensure there is strategic consistency among their performance measures, competitive methods, and the resulting organisational strategies. The lack of such strategic consistency will result in an inferior competitive position as organisational systems, performance measures, and overall strategies attempt to take the organisation in different directions. Therefore, today's organisations must invest in modern information system, which are capable of integrating the different competitive methods, performance dimensions, and strategic facets of the organisation. In addition, these organisations must reshape their organisational culture to promote cooperation and integration as opposed to sub-optimisation of certain functions or objectives. In this context, the role of top management to lead by example is underscored as the rest of the members of the organisation look to their senior executives for vision and strategic direction.

The conceptual framework of Figure 2 stresses the need to integrate these two important aspects of the open system organisation. It offers a process-driven approach to incorporate the performance management into the strategic management effort. Most of the studied organisations are in need of such a process-driven approach in order to enhance consistent strategic effectiveness.

The conceptual framework in Figure 2 also offers a road map toward facilitating the achievement of strategic consistency through the alignment of competitive methods, performance measures, and the intended strategic choice of the organisation. In this context, Figure 2 offers a practical road map toward ensuring the utilisation of innovative performance measures, competitive methods, and organisational choice of strategy.

The conceptual framework in Figure 2 has three stages. The first stage is the assessment stage. This stage focuses on the changes and challenges of the competitive environment. In this context, managers of today's open system organisations should examine closely the developments in the competitive environment, which have direct impact on their organisations. 
The second stage is the analysis stage. Using the rapid assessment methodology (RAM) which has been utilised in other settings, the managers of today's open system organisations should be able to gage threats, strengths, and capabilities pertaining to their organisation.

The third stage is the adjustment and alignment stage. In this stage, organisational performance measures, competitive methods, and the chosen organisational strategy should be modified, reengineered, and integrated in order to promote organisational consistency among these three important facets of the organisation.

This approach emphasises the interaction and openness of today's organisation to its environment, as it attempts to achieve effective strategic consistency. This, in turn, may contribute to gaining and maintaining a strategic competitive advantage for the organisation. The issue of strategic consistency is an important concern to today's organisations regardless of their environment and cultural realities. Therefore, more research is needed in this area. In this context, Figure 2 is proposed as a modest step in that direction.

While the sample utilised in this study is limited to Portuguese organisations, achieving such consistency should be relevant to other organisations in different cultural business settings. Therefore, the main contribution of the current study is to raise the interest of managers and students of this important practical area. Future research pertaining to this area should promote strategic consistent competitive performance which is demanding by the dynamic and customer oriented competitive environment. Integrating the three bodies of knowledge pertaining to performance measures, competitive methods and the resulting strategic orientation should facilitate integrated applied theoretical frameworks. In the past, under the closed system organisational approach, these important areas were dealt with discreetly which led to the lack of strategic consistency and strategic performance ineffectiveness. Today's business organisations have (for the most part) succeeded in shifting their business model toward the open system interactive approach. However, they still struggle with the consistency issue. In this context, the conceptual framework in Figure 2 is offered to both managers and researchers as they tackle the absence of consistent performance and competitive methods leading to an effective consistent performance and competitive strategy.

\section{References}

Aracioğlu, B., Zalluhoğlu, A.E. and Candemir, C. (2013) 'Measuring and evaluating performance within the strategic management perspective: a study on performance measurement of a seafood company', Procedia - Social and Behavioural Sciences, Vol. 99, pp.1026-1034.

Belkasseh, M. and Lemtaoui, M. (2015) 'Let's talk performance! Some hints', Review of Business and Finance Studies, Vol. 6, No. 3, pp.57-70.

Bhimani, A. (1993) 'Performance measures in UK manufacturing companies: the state of play', Management Accounting, Vol. 71, No. 11, pp.20-22, London.

Bisbe, J. and Malagueño, R. (2012) 'Using strategic performance measurement systems for strategy formulation: does it work in dynamic environments?', Management Accounting Research, Vol. 23, No. 4, pp.296-311.

Campbell-Hunt, C. (2000) 'What have we learned about generic competitive strategy? A meta-analysis', Strategic Management Journal, Vol. 21, No. 2, pp.127-154.

Cheng, J. and Yam, R.C.M. (2006) 'A study of the relationship between competitiveness and technological innovation capability based on DEA models', European Journal of Operational Research, Vol. 170, No. 3, pp.971-986. 
Davis, P.S. (1984) 'Porter' s (1980) generic strategies as determinants of strategic group membership and organizational performance', Academy of Management Journal, Vol. 27, No. 3, pp.467-488.

De Leeuw, S., Grotenhuis, R. and Van Goor, A.R. (2013) 'Assessing complexity of supply chains: evidence from wholesalers', International Journal of Operations and Production Management, Vol. 33, No. 8, pp.960-980.

Dempsey, S.J. et al. (1997) 'The use of strategic performance variables as leading indicators in financial analysts' forecasts', Journal of Financial Statement Analysis, Vol. 2, No. 4, pp.61-79.

Drucker, P.E. (1990) 'The emerging theory of manufacturing', Harvard Business Review, Vol. 68, No. 3, pp.94-102.

Foster, G. and Gupta, M. (1994) 'Marketing, cost management and management accounting', Journal of Management Accounting Research, Fall, Vol. 6, pp.43-47.

Gomes, C.F., Yasin, M.M. and Lisboa, J.V. (2004) 'An examination of manufacturing organizations performance evaluation: analysis, implications and a framework for future research', International Journal of Operations and Production Management, Vol. 24, No. 5, pp.488-513.

Gomes, C.F., Yasin, M.M. and Lisboa, J.V. (2006) 'Performance measurement practices in manufacturing firms: an empirical investigation', Journal of Manufacturing Technology Management, Vol. 17, No. 2, pp.144-167.

Grady, M.W. (1991) 'Performance measurement: implementing strategy', Management Accounting, Vol. 72, No. 12, pp.49-53.

Green, R., Lisboa, J.V. and Yasin, M. (1993) 'Porter's 1980 generic strategies in Portugal', European Business Review, Vol. 93, No. 2, pp.3-10.

Hanson, J.D., Melnyk, S.A. and Calantone, R.A. (2011) 'Defining and measuring alignment in performance management', International Journal of Operations and Production Management, Vol. 31, No. 10, pp.1089-1114.

Ho, J.L.Y., Wu, A. and Wu, S.Y.C. (2013) 'Performance measures, consensus on strategy implementation, and performance: evidence from the operational-level of organizations', Accounting, Organizations and Society, Vol. 39, No. 1, pp.38-58.

Hudson Smith, M. and Smith, D. (2007) 'Implementing strategically aligned performance measurement in small firms', International Journal of Production Economics, Vol. 106, No. 2, pp.393-408.

Jácome, R., Lisboa, J.V. and Yasin, M.M. (2002) 'Time-based differentiation - an old strategic hat or an effective strategic choice: an empirical investigation', European Business Review, Vol. 14, No. 3, pp.184-1993.

Jakobsen, M., Nørreklit, H. and Mitchell, F. (2010) 'Internal performance measurement systems: problems and solutions', Journal of Asia-Pacific Business, Vol. 11, No. 4, pp.258-277.

Lima, R.H.P., Guerrini, F.M. and Carpinetti, L.C.R. (2011) 'Performance measurement in collaborative networks: a proposal of performance indicators for the manufacturing industry', International Journal of Business Excellence, Vol. 4, No. 1, pp.61-79.

Maguire, S., Koh, S.C.L. and Magrys, A. (2007) 'The adoption of e-business and knowledge management in SMEs', Benchmarking: An International Journal, Vol. 14, No. 1, pp.37-58.

Marchand, M. and Raymond, L. (2008) 'Researching performance measurement systems: an information systems perspective', International Journal of Operations and Production Management, Vol. 28, No. 7, pp.663-686.

Marinho, S.V. and Cagnin, C. (2014) 'The roles of FTA in improving performance measurement systems to enable alignment between business strategy and operations: insights from three practical cases', Futures, Vol. 59, pp.50-61. 
Marques, A. et al. (2000) 'The effectiveness of strategies employed by dominant firms in the Portuguese crystal glass industry: an empirical investigation', European Business Review, Vol. 12, No. 1, pp.34-40.

McAdam, R., Hazlett, S-A. and Galbraith, B. (2014) 'The role of performance measurement models in multi level alignment: an exploratory case analysis in the utilities sector', International Journal of Operations and Production Management, Vol. 34, No. 9, pp.1153-1183.

McNair, C.J. and Mosconi, W. (1987) 'Measuring performance in an advanced manufacturing environment', Management Accounting, Vol. 69, No. 1, pp.28-31.

Melnyk, S.A. et al. (2014) 'Is performance measurement and management fit for the future?', Management Accounting Research, Vol. 25, No. 2, pp.173-186 [online] http://dx.doi.org/10.1016/j.mar.2013.07.007 (accessed 4 February 2014).

Meybodi, M.Z. (2015a) 'Consistency of strategic and tactical benchmarking performance measures', Benchmarking: An International Journal, Vol. 22, No. 6, pp.1019-1032.

Meybodi, M.Z. (2015b) 'The links between just-in-time practices and alignment of benchmarking performance measures', The TQM Journal, Vol. 27, No. 1, pp.108-121.

Okongwu, U., Brulhart, F. and Moncef, B. (2015) 'Causal linkages between supply chain management practices and performance', Journal of Manufacturing Technology Management, Vol. 26, No. 5, pp.678-702.

Olivella, J. and Gregorio, R. (2015) 'A case study of an integrated manufacturing performance measurement and meeting system', Journal of Manufacturing Technology Management, Vol. 26, No. 4, pp.515-535.

Oyewobi, L.O., Windapo, A.O. and Rotimi, J.O.B. (2015) 'Measuring strategic performance in construction companies: a proposed integrated model', Journal of Facilities Management, Vol. 13, No. 2, pp.109-132.

Porter, M.E. (1985) Competitive Advantage Creating and Sustaining Superior Performance, Free Press, New York.

Powell, T.C. (1992) 'Organizational alignment as competitive advantage', Strategic Management Journal, Vol. 13, No. 2, pp.119-134.

Sahu, A.K., Datta, S. and Mahapatra, S.S. (2014) 'Use of IVFNs and MULTIMOORA method for supply chain performance measurement, benchmarking and decision-making: an empirical study', International Journal of Business Excellence, Vol. 7, No. 2, pp.237-280.

Shahzileh, Z.H. and Aghajan, A.M. (2015) 'Performance appraisal: a review and case study', International Journal of Business Excellence, Vol. 8, No. 5, pp.584-600.

Srimai, S., Radford, J. and Wright, C. (2011) 'Evolutionary paths of performance measurement: an overview of its recent development', International Journal of Productivity and Performance Management, Vol. 60, No. 7, pp.662-687.

Taylor, A. and Taylor, M. (2013) 'Antecedents of effective performance measurement system implementation: an empirical study of UK manufacturing firms', International Journal of Production Research, Vol. 51, No. 18, pp.5485-5498.

Tung, A., Baird, K. and Schoch, H.P. (2011) 'Factors influencing the effectiveness of performance measurement systems', International Journal of Operations and Production Management, Vol. 31, No. 12, pp.1287-1310.

Turhan, D. and Vayvay, O. (2011) 'A performance-based decision-making tool for supply chain reengineering', International Journal of Business Excellence, Vol. 4, No. 3, pp.298-320.

Upadhaya, B., Munir, R. and Blount, Y. (2014) 'Association between performance measurement systems and organisational effectiveness', International Journal of Operations and Production Management, Vol. 34, No. 7, pp.853-875.

Veysel, A., Topal, Y. and Kaya, H. (2012) 'Linking intrapreneurship activities to multidimensional firm performance in Turkish manufacturing firms: an empirical study', International Entrepreneurship and Management Journal, Vol. 8, No. 1, pp.15-33. 